\title{
Model EFQM in agilnost organizacij
}

\author{
Patricija Kastelec ${ }^{*}$ \\ Fakulteta za organizacijske študije v Novem mestu, Ulica talcev 3, 8000 Novo mesto, \\ Slovenija \\ patricija1@gmail.com
}

\begin{abstract}
Povzetek:
Raziskovalno vprašanje (RV): Kakšen koristi ima organizacija, ki sledi modelu EFQM in svojo organizacijo preoblikuje $\mathrm{v}$ agilno organizacijo?

Namen: Namen raziskovanja je proučiti medsebojno povezavo med modelom EFQM, agilnostjo in agilno organizacijo, ter posledično hitrejšo prilagodljivostjo, večjo uspešnostjo ter konkurenčnostjo agilne organizacije.

Metoda: Članek smo naredili na podlagi pregleda tuje in domače literature. Pregledali smo strokovno literaturo na temo agilnosti in modela EFQM. Poiskali smo povezavo med agilnostjo in modelom EFQM.

Rezultati: Ugotovili bomo, da obstajajo razlike med agilnim menedžmentom in organizacijsko kulturo v organizacijah, ki so agilno ozaveščenih, od tistih, ki to niso. Za uspešne vodje agilne organizacije je bistvenega pomena, da razvijejo učinkovite komunikacijske in interakcijske spretnosti, ki so edinstvene za vodjo in organizacijo. Pomembno je, da posamezniki v organizaciji sprejmejo skupno vizijo, sodelujejo $\mathrm{v}$ kulturi zaupanja in vključevanja, medtem ko voditelji spodbujajo ustvarjalnost in eksperimentiranje.

Organizacija: Za agilno organizacijo velja, da je ta hitra (inovativna, agilna, prilagodljiva), in da je potrebno sprotno prenavljanje poslovanja. Raziskava bo opozorila na pomembnost in nujnost zavedanja menedžmenta, da bodo z ustvarjanjem določene organizacijske kulture in agilnim vodenjem organizacije dosegale hitrejše in učinkovitejše prilagajanje spremembam v okolju.

Družba: Pomanjkanje agilnega vodenja in ustvarjanja neustrezne organizacijske kulture ima negativen vpliv na zadovoljstvo vseh, ki so vključeni v proces (zaposleni, stranke, dobavitelji,...) in posledično na prilagajanje potrebam okolja.

Originalnost: Originalnost prispevka je $\mathrm{v}$ tem, da razbijemo mite o pojmu agilnosti in agilni organizacijo, ter pridobljene rezultate prikažem oziroma ovrednotim $\mathrm{z}$ rezultatom razlik med agilnimi in ne agilnimi oziroma tradicionalnimi organizacijami.

Omejitve/nadaljnje raziskovanje: Omejitev predstavlja manjše število člankov in literature izbranih za primerjavo. Na podlagi večjega vzorca člankov, bi dobili bolj relevantne rezultate. Prav tako smo našli malo člankov v slovenskem jeziku.
\end{abstract}

Ključne besede: poslovna odličnost, model EFQM, agilni menedžment, agilnost, agilna organizacija.

\section{Uvod}

Novi časi poslovanja zahtevajo nove pristope in načine vodenja. Ker potrebujemo hitrejše rešitve, potrebujemo drugačen način vodenja ter ostalih poslovnih procesov. Podjetja bijejo

* Korespondenčni avtor / Correspondence author 
bitko za preživetje ter morajo biti korak pred konkurenco. Če želijo na konkurenčnem trgu preživeti, morajo uvesti spremembo. Bežen pogled na statistiko pri velikih in majhnih podjetjih kaže, kako težko je nadaljevati življenje v okolju, ki ga rutinsko pretresajo izzivi, ki prihajajo iz različnih smeri. Ali šoki prihajajo iz smeri povečane konkurence, tehnološke spremembe, globalizacija trgov, povečana ureditev ali kateri koli od številnih drugih dejavnikov, učinek je enak - ustvari nestabilno in zelo turbulentno okolje. Spopadanje z izzivom ni enostavno niti za največja podjetja z najboljšimi viri v EU in na svetu. (Bessant, Knowles, Briffa, \& Francis, 2002, str. 484-488)

Danes si morajo organizacije prizadevati, da bi bila konkurenčna. Na nek način je filozofija TQM resnično priznana kot navdihujoča ideja, ki podpira ta trud in je tako imenovana oziroma poznana kot poslovna odličnost. Modeli so se kot učinkovita orodja na tem področju pojavili pred več kot 30 leti. (Nenadál, 2020, str. 18)

Sprememba je uspešna, če podjetje s spremenjeno strategijo nadgradi znanje, motiviranost in inovativnost svojih zaposlenih, preuredi poslovne procese ter njihovo organiziranost in $\mathrm{s}$ sodobnimi usmeritvami posodobi in uporabi informacijsko tehnologijo. Razvijanje, spreminjanje in prilagajanje poslovne strategije je trajna in najpomembnejša naloga vodstva podjetja. Poslovna strategija opredeljuje delovanje podjetja $\mathrm{v}$ poslovnem okolju in vpliva na njegovo konkurenčnost. (Kovačič, 2019, str. 39)

Spretnost delovanja in inovacijske sposobnosti, so vedno bolj potrebne za preživetje podjetja. Toda na trgu, kjer se tekmeci hitro soočijo s spremembami v obstoječih izdelkih in storitvah ter tam, kjer imajo moč na trgu, ki je odločilno preusmerjena na kupce, lahko podjetja težko zaslužijo te dobičke in izboljšave. Med močno konkurenco imajo kupci izbiro in dostop do zanesljivih informacij, zato vedno bolj zahtevajo izboljšanje kakovosti z nižjimi stroški ali brez stroškov. (Denning, 2017, str.12)

$\mathrm{V}$ članku bomo pregledali in razjasnili pojme o modelu EFQM in agilnosti. To nam bo v pomoč iskanju povezave med modelom EFQM in agilnostjo. Razjasnili in predstavili bomo povezavo med modelom EFQM in agilnem menedžmentom. Oprli se bomo na enega izmed osmih načel modela EFQM, to je agilni menedžment.

Namen raziskovanja je proučiti medsebojno povezavo med modelom EFQM in agilno organizacijo. Veliko organizacij še danes ne sledi ideji poslovne odličnosti, ne poznajo modela EFQM, posledično tudi ne agilnega pristopa. Cilj je raziskati razlike med organizacijami, ki so agilno ozaveščene, od tistih, ki to niso. Organizacije morajo spoznati, da je za uspešne vodje agilne organizacije bistvenega pomena, da razvijejo učinkovite komunikacijske in interakcijske spretnosti, ki so edinstvene za vodjo in organizacijo. Pomembno je, da posamezniki v organizaciji sprejmejo skupno vizijo, sodelujejo v kulturi zaupanja in vključevanja, medtem ko voditelji spodbujajo ustvarjalnost in eksperimentiranje. 


\section{Pregled literature}

\subsection{Odličnost in kakovost}

Od leta 1950 je bilo na znanstvenem področju veliko napisanega o upravljanju kakovosti in njegov življenjski pomen za preživetje podjetja. Japonska prizadevanja za rekonstrukcijo gospodarstva so bila povod za vrsto temeljnih sprememb v upravljanju, ki še vedno vplivajo na podjetja po vsem svetu. Kakovost je odgovornost vseh v podjetju. Preprečevanje in ne pregledovanje, usmerjenost $\mathrm{k}$ strankam, nenehno izboljševanje in vodenje kakovosti so nekatere ključne značilnosti podjetij, ki izvajajo načela popolnega upravljanja kakovosti (TQM), ki so bila sprva uporabljena na Japonskem in hitro sprejeta $\mathrm{v}$ ameriških in evropskih podjetjih (Go'mez \& Martı'nez Costa, 2010, str. 458).

Enotna definicija poimenovanja kakovosti ne obstaja, vsak avtor jo razlaga s svojimi stališči, znanjem in metodami. Kakovost lahko pomeni zelo različne stvari za različne ljudi, običajno pa je povezana $\mathrm{s}$ ceno in stroški. Kakovost ima lahko dvojni pomen: nanaša se na karakteristike izdelka ali storitve, ki oblikujejo potrebne sposobnosti za zadovoljevanje naprej določenih ali pričakovanih potreb kupcev ali pa se kakovost nanaša na izdelek in storitev, ki je brez napak. (Dolinšek et al., 2006, str. 35)

Po SSKJ-ju je definicija odličnosti: Odličnost je lastnost, značilnost odličnega. Bric (2013, str. 8-9) pa pravi, da »odličnost ni cilj, ampak pot!«»Odličnost je stanje duha. Je potovanje, vendar je pomembneje kako priti tja, kot biti tam.«»Pomeni izboljševanje in inovativnost; gre za omogočanje in doseganje stalnosti namena. Diamanti so večni, toda vedno lahko stremimo k briljantom «

Nemšak (2018, str. 1) pa pravi, da »odlične organizacije nenehno dvigujejo meje možnega. Negujejo kulturo doseganja izjemnih rezultatov, skrbijo za blagostanje ljudi in ohranjanje okolja. Odlične organizacije se ne osredotočajo le nase. Vse, kar delajo, delajo tudi za svoje okolje in družbo kot celoto. Vsakodnevno in dolgoročno udejanjajo načela poslovne odličnosti in prispevajo $\mathrm{k}$ njihovemu nadaljnjemu razvoju.«

Vidimo, da lahko kakovost pomeni različne stvari za različne ljudi, povezujemo pa jo s ceno in stroški. Da postanemo odlični, je potrebna pot, vendar pa je bolj pomembno kako priti do tja, kot pa biti tam.

\subsection{Poslovna odličnost}

$\mathrm{V}$ tem okolju nenehnih sprememb moramo znanje razumeti kot prednost življenjskega pomena. Nobena organizacija si ne more privoščiti, da bi ogrozila ali premalo izkoristila svoje znanje, katerega pridobi v okviru svoje dejavnosti. Poleg tega je treba stalno vzdrževati razmislek o tem, ali ima organizacija potrebno znanje za ponudbo izdelka oz storitev, glede na to, kaj stranka želi. Skratka, da bi bile organizacije konkurenčne, jih je treba nenehno ustvarjati in asimilirati nova znanja in spretnosti. Zato kakovost in odličnost kot filozofija 
upravljanja, ki temelji na stalnem izboljševanju, inovacijah in učenju, lahko služi za ustvarjanje konteksta in pogoje za razvoj trajnostnih konkurenčnih prednosti. Poleg tega pobude za upravljanje znanja nimajo pomena, če niso sistematično razvita. in tu je okvir, ki ga ponuja model odličnosti EFQM. (Criado-García, Calvo-Mora, \& Martelo-Landroguez, 2019, str. 15)

Kvas (2006, v Janjetovič, 2019, str. 2) pravi, da koncepti poslovne odličnosti skozi različne modele na standardiziran način vpeljujejo zavedanje o nenehnem izboljševanju poslovanja organizacije. Z načrtovanjem, izvajanjem in vpeljavo, ter spremljanjem potrebnih sprememb pa lahko zagotovimo ohranjanje odličnosti.

Kvas (2006, v Janjetovič, 2019, str. 2) opredeljuje tudi, da je pojem poslovna odličnost povezan $\mathrm{z}$ doseganjem velikega napredka ali izjemnih rezultatov $\mathrm{z}$ vidika uspešnosti, učinkovitosti, konkurenčnosti in ugleda posamezne organizacije $v$ daljšem, to je od tri- do petletnem obdobju, z upoštevanjem načel odličnosti. Novi časi zahtevajo nove pristope in načine vodenja. Ker potrebujemo hitrejše rešitve, potrebujemo drugačen način vodenja projektov ter ostalih poslovnih procesov. Podjetja bijejo bitko za preživetje, zato morajo biti korak pred konkurenco. $\mathrm{V}$ boju za tržni delež se morajo hitro odzvati na zahteve tržišča in izenačevati, če ne že nadgrajevati.

Poslovna odličnost se kaže predvsem v tem, da odlične organizacije nenehno dvigujejo meje možnega. Negujejo kulturo doseganja izjemnih rezultatov, skrbijo za blagostanje ljudi in ohranjanje okolja. Odlične organizacije se ne osredotočajo le nase. Delajo tudi za svoje okolje in družbo kot celoto. Vsakodnevno in dolgoročno udejanjajo načela poslovne odličnosti in prispevajo k njihovemu nadaljnjemu razvoju. (Nemšak, 2018, str. 1)

Danes si organizacije ne morejo privoščiti, da nebi izkoristile svojih znanj. Da pa bi bile organizacije konkurenčne, se morajo neprestano izobraževati, razvijati in učiti. Zato kakovost in odličnost kot filozofija upravljanja, ki temelji na stalnem izboljševanju, inovacijah in učenju, ustvarjata pogoje za razvoj trajnostnih konkurenčnih prednosti. Koncepti poslovne odličnosti vpeljujejo zavedanje o nenehnem izboljševanju poslovanja organizacije. Ker potrebujemo hitrejše rešitve, potrebujemo drugačen način vodenja. Podjetja morajo biti nenehno korak pred konkurenco. Poslovna odličnost pa se kaže predvsem v tem, da odlične organizacije nenehno dvigujejo meje možnega.

Ministrstvo za gospodarski razvoj in tehnologijo (2012, str. 4) je navedlo, da obstaja 8 temeljnih načel po EFQM 2012:

- Dodajanje vrednosti za odjemalce: Odlične organizacije dosledno dodajajo vrednost za odjemalce z razumevanjem, predvidevanjem in izpolnjevanjem potreb in pričakovanj ter izkoriščenjem priložnosti. 
- Ustvarjanje trajnostne prihodnosti: Odlične organizacije z izboljševanjem uspešnosti svojega delovanja pozitivno vplivajo na svet okoli sebe, s tem pa tudi na gospodarske, okoljske in družbene razmere v skupnostih, s katerimi so v stiku.

- Razvijanje sposobnosti organizacije: Odlične organizacije razvijajo svoje sposobnosti z uspešnim managementom sprememb znotraj in zunaj svojih meja.

- Spodbujanje ustvarjalnosti in inovativnosti: Odlične organizacije ustvarjajo višjo vrednost in raven uspešnosti svojega delovanja $s$ stalnim izboljševanjem in sistematičnim inoviranjem, tako da izkoristijo ustvarjalnost svojih deležnikov.

- Vodenje z vizijo, navdihom in integriteto: Odlične organizacije imajo voditelje, ki oblikujejo in udejanjajo prihodnost ter so zgled vrednot in etičnih načel organizacije.

- Agilni menedžment: Odlične organizacije so splošno priznane zaradi svoje sposobnosti prepoznavanja ter uspešnega in učinkovitega odzivanja na priložnosti in nevarnosti.

- Doseganje uspehov z nadarjenostjo zaposlenih: Odlične organizacije cenijo svoje zaposlene ter ustvarjajo kulturo pooblaščanja za doseganje ciljev organizacije in osebnih ciljev zaposlenih.

- Trajno doseganje izvrstnih rezultatov: Odlične organizacije dosegajo na svojem področju delovanja trajno izvrstne rezultate, ki izpolnjujejo tako kratkoročne kot dolgoročne potrebe vseh njihovih deležnikov.

Na spodnji sliki (slika 1) prikazujemo temeljna načela odličnosti po EFQM, ki smo jih opisali zgoraj.

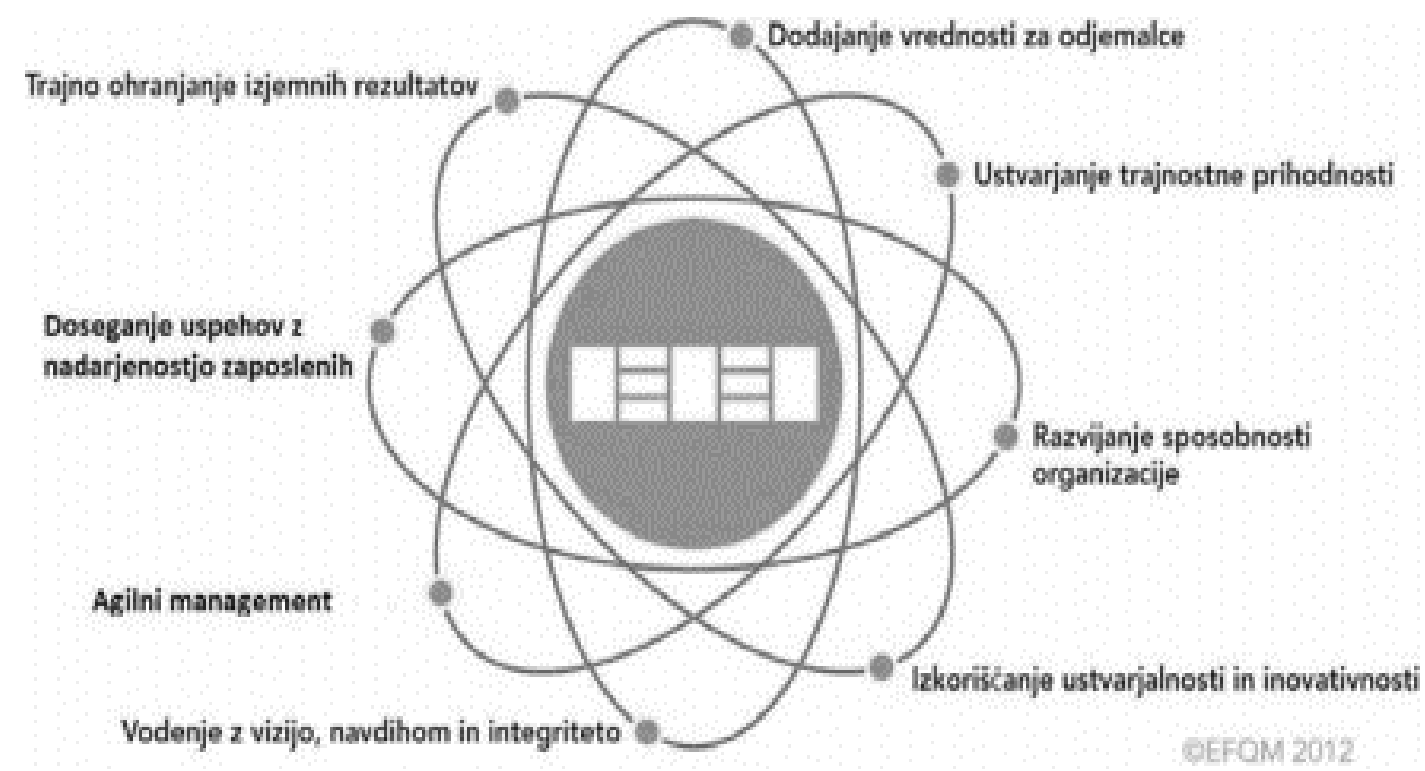

Slika 1. Temeljna načela odličnosti po EFQM 2012. Povzeto iz »Ministrstvo za gospodarski razvoj in tehnologijo« 2012, Spirit, podjetniški portal, str. 4) 


\subsection{Model odličnosti EFQM}

Model je splošno priznan kot reprezentativna teorija za izboljšanje tradicionalnega seštevka obvladovanja kakovosti (TQM) s širjenjem ozkega kakovostno usmerjenega koncepta $\mathrm{v}$ koncept celostnega upravljanja. Model EFQM, integrativni poslovni sistem, zajema vse upravljavske dejavnosti, sestavljene iz vhodnih podatkov, procesov in izhodnih podatkov. (Kim, Kumar, \& Murphy, 2010, str. 684)

Vprašanje je: kaj je naslednji korak za evropska podjetja? Zdi se, da je odgovor na to vprašanje lahko model EFQM. Ta se uporablja $\mathrm{v}$ podjetjih in drugih organizacijah $\mathrm{z}$ naraščajočo hitrostjo. (Gómez, Costa, \& Lorente, 2011, str. 485)

Kako oceniti uspešnost podjetja z uporabo modela odličnosti in kakšne koristi prinese organizaciji, so teme, o katerih se pogosto govori. Pristop modela odličnosti EFQM vsebuje številna merila ki so razdeljeni na pod-kriterije in so namenjeni obravnavanju vseh vidikov za organizacije (Rusjan, 2005, str. 363-364). Elementi modela EFQM ustvarjajo razmeroma jasno pot, kateri mora podjetje slediti, da bi izboljšali njegove rezultate. (Gómez, Costa, \& Lorente, 2011, str. 485)

Danes organizacije priznavajo, da znanje in učinkovito upravljanje predstavljata temeljni vir trajnostne konkurenčne prednosti in sta ključ za uspeh organizacije. Zato morajo organizacije uporabljati modele in sisteme za upravljanje znanja, cilj pri tem pa je povečanje njihove konkurenčne prednosti. (Criado-García, Calvo-Mora, \& Martelo-Landroguez, 2019, str. 1)

$\mathrm{V}$ ta namen se študija začne $\mathrm{z}$ opisom EFQM-ja in elementov, ki se integrirajo, kot tudi predstavitev osnov tega, kar pomeni znanje in njegovo upravljanje. Sem štejemo koncepte odličnosti, ki postavljajo temelje za doseganje trajne odličnosti v kateri koli organizaciji. Temeljni koncepti odličnosti so (po EFQM, 2012): vodenje z vizijo, navdihom in integriteto; uspeti s talentom ljudi; izkoriščanje ustvarjalnosti in inovativnosti; razvoj organizacijske sposobnosti; upravljanje z okretnostjo; dodana vrednost za stranke; ustvarjanje trajnostne prihodnosti; in vzdrževanje izjemnih rezultatov. Omenjena načela so prevedena in opredeljena $\mathrm{v}$ devetih razsežnostih ali merilih, ki služijo kot vodilo za izvajanje upravljanja sistema in merjenja rezultatov, ki jih doseže organizacija.

EFQM (2012, v Criado-García, Calvo-Mora, \& Martelo-Landroguez, 2019, str. 11) navajajo, da merila, ki jih predlaga model, predstavlja elemente, ki kažejo na stopnjo napredovanja, ki $\mathrm{mu}$ določena organizacija sledi za doseganje odličnosti. Ta merila so razvrščena $\mathrm{v}$ pet kategorij (vodstvo, strategija, ljudje, partnerstva in viri, in procesi), preostale štiri dimenzije pa odražajo rezultate, ki jih organizacija doseže (rezultati strank, rezultati ljudi, rezultati družbe in rezultati podjetja). Vsako merilo pa vsebuje spremenljivo število pod-kriterijev. Model EFQM skupaj vključuje 32 podkriterij, ki jih je treba upoštevati. Na koncu pa vsak pod-kriterij vključuje seznam elementov, ki niso niti izčrpni niti obvezni za obravnavo, cilj, ki naj bi zagotovil primere, ki pojasnjujejo pomen podmeril in vodijo samoocenjevanje 
organizacije. EFQM ima dinamično naravo, navedbo, katere dejavnosti, kot so inovacije, učenje ali ustvarjalnost, spodbujajo in krepijo organizacijo, ki ga omogočajo modeli za dosego rezultatov. To se nanaša na neprekinjeno izboljšanje sistema kakovosti v iskanju odličnosti. Vendar EFQM ni sklop nepovezanih meril. Nasprotno, predstavlja vrsto povezanih praks, ki ponujajo večjo kontinuiteto in skladnost. (Criado-García, Calvo-Mora, \& MarteloLandroguez, 2019, str.11)

Poleg tega bo organizacija pridobila potrebno znanje, ki ga določa okolje in kateri so ključni elementi za tekmovanje znotraj njega. Model pomaga, da organizacija vzdržuje odnose s svojimi glavnimi partnerji (dobavitelji, kupci, distributerji in konkurenti). EFQM vključuje zahteve in smernice glede integracije kupcev, dobaviteljev in partnerjev za izmenjavo priložnosti, izkušenj, znanja in na koncu optimizirati zavezništva z zainteresiranimi stranmi. (Nenadál, 2020, str. 22)

Model odličnosti EFQM temelji na sklopu evropskih vrednot, prvič izraženih v Evropski konvenciji o človekovih pravicah (1953) in Evropski socialni listini (1996). To pogodbo je ratificiralo 47 držav članic Sveta Evrope, njena načela pa so vključena $v$ nacionalne zakonodaje. Temeljna načela odličnosti se oblikujejo na podlagi teh temeljnih človekovih pravic ob domnevi, da so splošno veljavne. Ob zavedanju vloge, ki jo lahko ima podjetništvo pri podpiranju širših ciljev Združenih narodov, je bila ustanovljena organizacija UN Global Compact (2000). Gre za pobudo, ki spodbuja organizacije, da pri svojem delovanju uveljavljajo vrednote, ki jih vsebuje deset načel za trajnostno in družbeno odgovorno podjetništvo. Čeprav je del teh načel izrecno zajet v modelu odličnosti EFQM, jih je nekaj implicitnih, vključno s tistimi, ki se nanašajo na človekove pravice, korupcijo, podkupovanje in prisilno delo, ker so v Evropi že zakonsko predpisana. Model odličnosti EFQM predvideva, da bo odlična organizacija spoštovala in upoštevala deset načel UN Global Compact ne glede na to, ali jih zakon k temu obvezuje ali ne. (Ministrstvo za gospodarski razvoj in tehnologijo, 2012, str. 1)

Organizacija, ki želi biti uspešna, mora ne glede na svojo panogo, velikost, strukturo ali zrelost vzpostaviti ustrezen sistem menedžmenta. Model odličnosti EFQM je praktično, neobvezujoče orodje, ki organizacijam (Ministrstvo za gospodarski razvoj in tehnologijo, 2012, str. 2):

- omogoča oceniti, kje na poti k odličnosti so; pomaga jim razumeti lastne ključne prednosti ter morebitno vrzel z njihovo izjavo o viziji in poslanstvu,

- daje skupni jezik in način razmišljanja, kar olajša uspešno komuniciranje $\mathrm{v}$ organizaciji in zunaj nje,

- omogoča povezavo med obstoječimi in načrtovanimi pobudami, preprečuje podvajanje in zagotavlja prepoznavo vrzeli,

- daje osnovno strukturo sistema menedžmenta organizacije. 
Obstajajo številna orodja in tehnike menedžmenta, vendar model EFQM omogoča celovit pogled na organizacijo in ga organizacija lahko uporablja za ugotavljanje medsebojne usklajenosti in komplementarnosti teh metod. Zato je mogoče poseči po njem $\mathrm{v}$ povezavi s katerim koli izmed številnih orodij, odvisno od potreb in dejavnosti organizacije, kot po splošnem okviru za razvijanje trajne odličnosti. Odlične organizacije dosegajo in trajno ohranjajo izvrstne ravni delovanja, ki izpolnjujejo ali presegajo pričakovanja vseh njihovih deležnikov. Vse organizacije si prizadevajo biti uspešne, nekaterim spodleti, nekatere dosežejo obdobja uspeha, a na koncu izginejo z obzorja, nekaj pa jih doseže trajen uspeh ter uživajo zasluženo spoštovanje in občudovanje. (Ministrstvo za gospodarski razvoj in tehnologijo, 2012, str. 2)

Model daje poudarek zlasti razvoju zaposlenih, kreativnosti in inovativnosti, trajnosti, družbeni odgovornosti organizacije, gibčnosti organizacije, managementu tveganj, promociji izdelkov in storitev, managementu dobaviteljev. Rezultati pa so usmerjeni na ključne rezultate, ki so potrebni, da se doseže vizijo in strategijo organizacije. (Kern \& Leon, 2010, str. 4)

Nenadál (2020, str. 20) navaja, da model odličnosti EFQM obsega tri integrirane sestavne dele:

- Temeljni koncepti odličnosti. Imeli so osem načel organizacijske odličnosti: dodana vrednost za stranke, ustvarjanje trajnostne prihodnosti, razvoj organizacijske sposobnosti, izkoriščanje ustvarjalnosti in inovativnosti, vodenje z vizijo, navdihom in integriteto, vodenje $\mathrm{z}$ gibčnostjo, uspeh $\mathrm{s}$ talentom ljudi, ohranjanju izjemnih rezultatov.

- Merila so kot okvir za pomoč organizacijam pri pretvorbi temeljnih konceptov v praksi.

- RADAR logika kot okvir za dinamično ocenjevanje, ki omogoča izračunati celotno raven organizacijske odličnosti (zrelost) do usmerjanja in odkrivanja področij za izboljšanje upravljanja sistema.

Model odličnosti EFQM je predpisani okvir, ki priznava, da obstaja veliko pristopov $\mathrm{k}$ doseganju trajnostne organizacijske odličnosti. Odličnost je lahko opredeljena kot izjemna praksa pri vodenju organizacije in doseganju rezultatov, ki temelji na temeljnih konceptih, ki vključujejo: usmerjenost k rezultatom, osredotočenost na kupca, stalnost namena, postopki in dejstva, vključevanje ljudi, neprekinjeno izboljšanje in inovacije, vzajemno koristna partnerstva in javna odgovornost. Vedenja, dejavnosti ali pobude, ki temeljijo na teh konceptih, se pogosto imenujejo kakovost. Model EFQM temelji na devetih merilih in trdi, da so ob spoštovanju dosegajo odlični rezultati. Model odličnosti EFQM omogoča odkrivanje njegovih prednosti, pa tudi področij, na katerih se je mogoče izboljšati. Rusjan (2005, str. 368) navaja, da bi lahko zato model odličnosti EFQM uporabili kot motor za izboljšanje, kot je:

- $\quad$ primerjave rezultatov z notranjimi cilji, konkurenti ali podobnimi organizacijami in 
- 'najboljše v razredu' organizacije bi (morale) uporabiti za določanje prednostnih nalog in spodbujanje izboljšav.

V idealnem primeru postopek samoocenjevanja doseže vrhunec v načrtovanih izboljšavah, ki nato spremljajo napredek. (Rusjan, 2005, str. 368)

Evropska fundacija za vodenje kakovosti (2006); Kim, Kumar in Murphy (2010, str. 685) navajajo, da se v organizacijah model EFQM uporablja na različne načine:

- kot orodje za samoocenjevanje;

- kot način za primerjavo z drugimi organizacijami;

- kot vodilo za določitev področij za izboljšanje;

- kot osnova za skupni besednjak in način razmišljanja; in

- kot struktura sistema upravljanja organizacije.

\subsection{Agilni menedžment in agilnost}

Globalizacija in digitalizacija sta v veliki meri pripomogla $\mathrm{k}$ temu, da je poslovno okolje postalo zelo nestabilno in nepredvidljivo. Podjetja in druge organizacije so tako vključene $\mathrm{v}$ stalen proces preoblikovanja in negotovosti. Zato je razumljivo, da tako menedžerska teorija kot praksa iščeta modele ter organizacijske in upravljavske koncepte, ki bi menedžerjem omogočili učinkovito obvladovanje težav, s katerimi se soočajo. Začetki agilnih organizacij segajo od začetkov projektov razvoja programske opreme in so se postopoma razširili na splošno vodenje in organizacijo. Izraz 'okreten' in 'agilen' je sinonim za hitro in učinkovito prilagajanje okoljskih zahtev. (Gajšek \& Kovač, 2019, str. 1)

Za manjša podjetja je grožnja veliko večja, vse več preživijo le najmočnejša podjetja. Poslovanje se je od nekdaj ukvarjalo v kompleksnih in turbulentnih okoljih. Vendar se poudarja potreba po odzivu, ki temelji na sposobnosti prilagajanja, spreminjanja in priprave novih načinov za spopadanje z izzivom - in morda spreminjanjem pravil igre. Obravnavanje turbulentnih in spreminjajočih se okolij zahteva kombinacije sprememb in sposobnost uporabe inovativnih zmogljivosti za spopadanje z izzivi. Še vedno pa se večina inovacij bolj ukvarja z postopnim reševanjem problemov - nenehno izboljšanjem stvari znotraj obstoječega okvira, namesto da bi preoblikovali pravila igre. (Bessant, Knowles, Briffa, \& Francis, 2002, str. 458)

Podjetja in druge organizacije se soočajo s ponavljajočim zahtevam po temeljiti preučitvi njihove organiziranosti in sprejetih strateških usmeritev. Gajšek in Kovač (2019, str. 3) sta navedla razloge za navedene zahteve, ki se kažejo predvsem v:

- globalizacija ter z njo povezani naraščajoči konkurenčni tekmi na trgih;

- vstopanju v digitalno dobo in zahtevo po spremembi obstoječih poslovnih modelov;

- naraščajoči kompleksnosti in dinamičnosti okolja, ki jih zahtevajo podjetja v drugih organizacijah za skrajšanje ure odzivnosti. 
Odlične organizacije so splošno priznane zaradi svoje sposobnosti prepoznavanja ter uspešnega in učinkovitega odzivanja na priložnosti in nevarnosti. Ministrstvo za gospodarski razvoj in tehnologijo (2012, str. 7) navaja, da v praksi velja, da odlične organizacije:

- uporabljajo mehanizme za prepoznavanje sprememb v svojem zunanjem okolju in jih pretvorijo v potencialne prihodnje scenarije za organizacijo;

- usmerjajo procese, projekte in organizacijske strukture glede na svojo strategijo, $\mathrm{s}$ čimer zagotavljajo, da se spremembe lahko izvedejo z ustrezno hitrostjo po celotni verigi vrednosti;

- razvijajo smiselno kombinacijo kazalnikov uspešnosti delovanja procesov in z njimi povezanih končnih rezultatov, ki omogočajo pregled učinkovitosti in uspešnosti ključnih procesov ter njihovega prispevka k strateškim ciljem;

- uporabljajo podatke o trenutni uspešnosti delovanja in sposobnostih svojih procesov, pa tudi ustrezne primerjave $\mathrm{z}$ dosežki najboljših za spodbujanje ustvarjalnosti, inovativnosti in izboljšav;

- uspešno obvladujejo spremembe $\mathrm{s}$ strukturiranim vodenjem projektov in ciljno usmerjenim izboljševanjem procesov;

- hitro prilagodijo svojo organizacijsko strukturo za podporo doseganju strateških ciljev;

- vrednotijo in razvijajo tehnološki portfelj, da bi izboljšali agilnost procesov, projektov in organizacije.

Agilnost je povezana s sposobnostjo organizacije, da postane konkurenčna, krepi prednost z inteligentnim, hitrim in proaktivnim izkoriščanjem priložnosti in odzivanjem na grožnje. V svojem središču vključuje sposobnost strateškega usmerjanja inovativnih zmogljivosti. Agilnost ni novi izraz - izzivi na negotova okolja so vedno obstajali. Toda uganka in rešitve zanjo se sčasoma spreminjajo, tako da včerajšnje težave in rešitve morda ne bodo pomembne za prihodnost. V bistvu je agilnost preprost koncept - izziv je pri njegovi izvedbi v določenih organizacijah (Bessant, Knowles, Briffa, \& Francis, 2002, str. 487). Danes v večini podjetjih, ki izvajajo neko obliko agilnega upravljanja, z izboljšanjem učinkovitosti ali izboljšanjem kakovosti, omogočajo ekipi, enoti ali celemu podjetju, da se z hitro spreminjajočo se tehnologijo prilagodijo in nadgradijo obstoječe izdelke in storitve za zadovoljitev potreb strank. (Denning, 2017, str. 12)

Slovar tujk (SSKJ) opredeli pojem agilen kot delaven, marljiv, prizadeven, spreten, gibčen, živahen. Vendar ne govori o spretnem in prizadevnem projektnem pristopu, zato je smiselno uporabljati pojma agilno in agilnost. (Gajšek \& Kovač, 2019, str. 3)

Gajšek in Kovač (2019, str. 3) po drugih avtorjih, kot na primer (Nir, 2017), govorita celo o 'Agilni revoluciji'. Profesor Julina Birkinshaw iz London Business School je prepričan, da vstopamo v 'agilno dobo'. Organizacije, ki jim bo uspelo prehoditi v 'agilno dobo', zapuščajo za seboj značilnosti 'industrije dobe', ki temelji na odmerjanju učinkovitosti s pomočjo birokracije in značilnosti 'informacijske dobe', katere značilnosti so bile v skladu s pravilnimi odgovori uporaba načrtovanja in racionalne analize. To je samo nekaj pojavov uporabe pojma 
'agilen' v izredno obsežni produkciji strokovne literature na področju organizacij in menedžmenta. (Gajšek \& Kovač, 2019, str. 4)

Pojem 'agilen' se danes pojavlja v različnih pomenskih povezavah na področju organizacijskih in upravljavskih ved. Iz posameznih primerov uporabe lahko vzamemo, da je pojem 'agilen' povezan z dejavniki kot so čas, stroški, kompetenca, fleksibilnost ter reaktivnost in proaktivno odzivanje sprememb $\mathrm{v}$ okolici, ki temelji na fokusu zadovoljstva poslovnih partnerjev. (Gajšek \& Kovač, 2019, str. 4)

Janeš (2019, str. 2) navaja po drugih avtorjih, kot so Nagi in Sanchez (2001), Biloslavo in Faganel (2017), da ima agilnost tri osnovne sestavne dele, ki zagotavljajo dodano vrednost za kupce: pripravljenost na spremembe, spoštovanje in upoštevanje znanja in veščin zaposlenih ter oblikovanje virtualnih partnerstev.

Del pogostega problema $\mathrm{v}$ mnogih organizacijah je, da vodstvo porabi preveč časa za sprejemanje uspešnih odločitev. Agilnost zato zahteva vpeto vodstvo, ki olajšuje izmenjavo znanja, išče soglasje, zaupa ljudem, delegira več in zagotavlja takšno delovno okolje za ljudi, da slednji kar najbolj vključujejo tiho znanje. (Nold, 2012, Nold \& Michel, 2016, str. 1)

Za uspešne vodje agilne organizacije je bistvenega pomena, da razvijejo učinkovite komunikacijske in interakcijske spretnosti, ki so edinstvene za vodjo in organizacijo. Pomembno je, da posamezniki v organizaciji sprejmejo skupno vizijo, sodelujejo v kulturi zaupanja in vključevanja, medtem ko voditelji spodbujajo ustvarjalnost in eksperimentiranje. Specifične strategije komuniciranja in interakcije se bodo razlikovale med organizacijami in vodji, vendar so prevladujoči cilji za skupno vizijo, sodelovanje in pozitivne odnose pomembni za vključitev v kulturo organizacije. (Nold \& Michel, 2016, str. 1)

Agilnost je odvisna od sestave kulture, vodenja in sistemov na način, da se čim bolj poveča pretok znanja $\mathrm{v}$ organizaciji, ter se tako razvijejo dinamične zmogljivosti in omogoči učinkovito in pravočasno sprejemanje odločitev. Karkoli manj od tega lahko povzroči, da organizacija ne bo uspela izkoristiti polne zmogljivosti za uspešnost. Posledica tega je lahko, da jo prehitijo in prevzamejo konkurenti, ki so bolj agilni. (Nold \& Michel, 2016, str. 1)

$\mathrm{V}$ novih okoliščinah torej ni dovolj biti velik, potrebno je biti hiter (inovativen, agilen, prilagodljiv), potrebno je sprotno prenavljanje poslovanja. Zato je potreben drugačen poslovni model; vse pomembnejša pa postajata pripravljenost in sposobnost hitrega in ustreznega prilagajanja spremembam. (Kovačič, 2019, str. 39)

Agilna organizacija ima »zmožnosti za razvoj in hitro uporabo prilagodljivih zmogljivosti« sprememb v okolju. Agilnost je ključni dejavnik ohranjanja konkurenčne prednosti in zagotovilo za njihovo preživetje. Agilnost predstavlja sposobnost organizacije, da se kontinuirano prilagaja na kompleksno in turbulentno okolje. 
Agilna organizacija pomeni mreža timov s prevladujočo organizacijsko kulturo, ki je usmerjena na posameznika in deluje na podlagi hitrejšega skupnega učenja ter odločitve podprtega s sodobno tehnologijo. Člane organizacije združujejo močne skupne vrednote v usmerjenost na ustvarjanje dodane vrednosti za vse deležnike. Agilna organizacija omogoča hitro prilagajanje $\mathrm{v}$ nepredvidljivih, negotovih, kompleksnih in nejasnih okoljih, kar predstavlja konkurenčno prednost pred drugimi (Gajšek \& Kovač, 2019, str. 5-7). Agilna organizacija predstavlja spremembo miselnosti, ki organizacijam omogoča hitrejše odzive na zahteve okolja. Hkrati pa izgrajujejo 'odpornost' organizacije s pomočjo skupinskega učenja njenih članov. Predvsem sposobnost hitrejšega učenja je pomembna značilnost agilne organizacije, ki jo odlikuje tudi osredotočanje na potrebe poslovnih partnerjev. (Gajšek \& Kovač, 2019, str. 5-7)

Gajšek in Kovač (2019, str. 5) navajata, da agilna organizacija pomeni:

- sposobnost organizacije za hitro prilagajanje spremembam v okolici,

- konkurenčna prednost,

- učinkovit proces učenja članov organizacij,

- obstoj močnih skupnih vrednot,

- osredotočenje na potrebe poslovnih partnerjev in hitro hitro odzivanje na njihove potrebe.

Ključne značilnosti agilnih organizacij pa so prepoznane v (Gajšek \& Kovač, 2019, str. 7):

- sprejeti strategije agilnosti na ravni organizacij (potrditev skupnih strateških zavez za agilnost in izgradnjo celovitega sistema za analizo in načrtovanje okolja);

- prilagodljivi organizacijski strukturi, ki temelji na časovni obliki z med-funkcijsko strukturo, ki je močno decentralizirana ter ima mrežno obliko;

- agilnem stilu vodenja, ki vključuje vključitev podrejenih v učinkovit postopek odločanja, polno zaposlene, uporabo novih instrumentov vodenja)

- agilnih posameznikov, katerih značilnosti so tako visoke stopnje zadovoljstva, samoorganizacija, visoka stopnja izražene pripadnosti organizacij in zavzetosti pri delu;

- izvajanje koncepta trajnostnega razvoja, ki predstavlja prevladujočo paradigmo pri organizaciji, ki zasledujejo dolgoročno uspešnost.

Gajšek in Kovač (2019, str. 7) navajata, da avtorji agilnega organizacijskega koncepta pri McKinseyu predvidevajo naslednjih pet značilnosti agilnih organizacij:

- soustvarjanje vrednosti z in za vse deležnike - V agilnih organizacijah obstaja močan skupni namen in vizija $\mathrm{s}$ prilagodljivimi, porazdeljenim pristopom $\mathrm{k}$ ustvarjanju vrednosti. Nenehno spremlja spremembe v svojih poslovnih okoljih in išče povratne informacije poslovnih partnerjev na različne načine;

- organiziranost, ki temelji na mreži majhnih, visoko zmogljivih timov z visoko stopnjo lastne avtonomije. Agilne organizacije sicer ohranjajo stabilno organizacijsko 
strukturo, ki pa jo sestavlja obsežno mrežo avtonomnih timov, ki delujejo na podlagi skupnih standardov usklajevanja, odgovornosti, strokovnosti in preglednosti;

- hitri, iterativni cikli učenja in odločanja - Agilne organizacije delujejo na podlagi hitrih ciklov učenja, odločanja in delovanja. Osnovo predstavlja učinkovito strukturno integracijo med razvojnimi in izvedbenimi procesi;

- organizacijska kultura in vodenje usmerjeno $\mathrm{k}$ ljudem - organizacijska kultura $\mathrm{v}$ agilnih organizacijah postavlja $\mathrm{v}$ središče posameznika in njegovo povezanost $\mathrm{v}$ skupnost s pomočjo močnih skupnih vrednosti. Agilni voditelji delujejo kot vizionarji in trenerji, ki niso načrtovani ali kontrolirani;

- uporaba sodobnih digitalnih tehnologij - agilne organizacije bodo morale obstoječe izdelke ali storitve zasnovati na novih digitalnih tehnologijah, ki bodo zadovoljivo spreminjale zahteve poslovnih partnerjev.

Pavlič in Brezočnik (2017, str. 80) navajata, da agilne metode sledijo vrednotam, ki so zbrane $\mathrm{v}$ agilnem manifestu. Agilne, vitke, praviloma iterativne razvojne metode udejanjajo preko več uveljavljenih pristopov, kot so:

- redni dnevni sestanki,

- izvajanje retrospektiv ob določenih mejnikih, tipično ob koncu iteracije,

- redne demonstracije izdelkov,

- ciljno usmerjeno delo v času iteracij,

- kratkoročno planiranje na osnovi prioritet.

Način dela je organiziran v »PDCA«(Plan-Do-Check-Adjust) cikle s sprotnimi kontrolnimi točkami (Pavlič \& Brezočnik, 2017, str. 80):

- definiranje in zaveza merljivemu cilju,

- definiranje obvladljivih (majhnih) in vidnih korakov (nalog) do cilja,

- izvedba nalog,

- sprotno merjenje napredka,

- refleksija, uvedba izboljšav in ponovitev.

\subsection{Stanje agilnosti v Sloveniji}

$\mathrm{V}$ nadaljevanju predstavljamo interpretacijo raziskave, ki pravi, da je agilnost tesno povezana $\mathrm{z}$ miselnostjo in to pomeni, da če uporabljaš neko agilno metodo še nisi agilen.

Kutnik (2012, str.1) pravi, da je kakovost članov agilnih ekip zelo pomembna, saj se pričakuje, da je agilna ekipa samoorganizirana in sposobna sama razviti produkt brez zunanje pomoči. Eden izmed principov agilnega manifesta namreč pravi, da nenehna težnja k tehnični odličnosti izboljša agilnost. To pomeni, da morajo imeti člani zelo dobro tehnično znanje, biti morajo zelo motivirani ter se nenehno izboljševati.

Raziskava o stanju agilnosti v Sloveniji (CorboHub, 2019, str. 2-8), katera je bila izvedena v letu 2019, pravi, da je večina podjetij, ki so bila anketirana, že uporabljajo agilno 
metodologijo in da so izrazi, ki se navezujejo na agilnost, organizacijam večinoma dobro znani. Raziskava je pokazala, da so se organizacije na agilnost prilagodile le deloma, saj agilne metodologije uporabljajo le določeni oddelki v organizacijah. Organizacij, ki v celoti uporabljajo agilne metodologije, pa je še vedno zelo malo. Prav tako organizacijam in posameznikom še vedno ni jasna definicija 'agile'- vsak posameznik opisuje agilno v svojem lastnem razumevanju.

Pri uvedbi agilnosti v organizacijo je glavno vprašanje še vedno splošni odpor do sprememb. Glavni razlog za uvedbo agilnosti pa so izboljšanje učinkovitosti ekipe. Organizacije kot prednost agilne organizacije opazijo izboljšano preglednost pri poslovanju. V primerjavi z letom 2018 (CorboHub, 2019, str. 2) je agilno metodologijo uporabljalo $30 \%$ manj anketiranih, kar jasno kaže na naraščanje agilnosti v organizacijah. (CorboHub, 2019, str. 2).

Najpogostejša razlaga, ki se uporablja pri razlaganju pojma 'agile' se razlaga kot prožnost in sposobnost prilagajanja spremembam. Med 130 odgovori, noben odgovor ni bil popolnoma enak. Različne so bile tudi razlage, kako agilne organizacije razumejo način razvoja, načina dela, splošne miselnosti, značilnosti ekip, sposobnosti in drugih lastnosti, ki veljajo za agilne organizacije.

Nekaj primerov, kako anketirani 'vidijo' agilno organizacijo (CorboHub, 2019, str. 4):

- Sposobnost hitrega odziva na spremembe na trgu / v tehnologiji.

- Sposobnost prilagajanja s ciljem večje učinkovitosti delovnih procesov.

- Učinkovito vodstvo.

- Način dela s stalno prilagodljivostjo in izboljšavami.

- Hitrost, prilagodljivost, odzivnost.

- Pristop k optimizaciji dela in razvoju izdelkov.

- Sposobnost hitrega in kakovostnega dela.

- Prilagodljivost, osredotočenost, usmerjenost k cilju, timsko delo.

- Hitro zagotavljanje vrednosti.

- Iterativni postopek razvoja izdelkov.

- Prilagodljivost za zahteve strank.

- Sposobnost hitrega odzivanja.

Anketirani čutijo prisotnost agilne kulture $\mathrm{v}$ organizacijah, kjer delajo, vendar je raziskava pokazala, da lahko s povprečjem $57 \%$ trdimo, da večina organizacij v Sloveniji še zdaleč ne živi in diha agilne kulture.

V raziskavi o stanju agilnosti Slovenije (CorboHub, 2019, str. 2-8) je bilo v raziskavo zajetih $86 \%$ organizacij, katera so že pridobila certifikat, kar nakazuje, da organizacija posluje agilno.

Bistvo agilnosti ni v tem, da delo v takem okolju ni nikoli monotono in dolgočasno, da se poslovni modeli lahko hitro spreminjajo (kar za nobeno podjetje ne drži) ter da podjetje nikoli 
ne zapade $\mathrm{v}$ rutino. Bistvo je $\mathrm{v}$ ljudeh - da se znajo hitro obrniti v začetnem bolj turbulentnem obdobju, da imajo dovolj znanj in da jim lahko pri dodeljevanju nalog zaupamo.

\section{Metoda}

Če želijo biti organizacije uspešne, se morajo preoblikovati. Zato smo si pogledali nekaj dobrih poslovnih praks na temo agilnosti.

Članek smo napisali na podlagi pregleda tuje in domače literature. Prevladuje deskriptivna metoda pri predstavitvi pojmov, opisovanju pojavov in povzemanju opazovanj in sklepov drugih avtorjev. Uporabljena metoda je temeljila na preučevanju teoretične podlage, pri čemer smo izbrali vir domače in tuje strokovne literature ter člankov. Identificirali smo vrzeli na področju kakovosti, modela EFQM. Največji poudarek smo namenili predstavitvi agilnosti. Empirični del raziskave je kvalitativen, podatke smo zbirali s pomočjo pridobljenih raziskav, katere smo potem kritično interpretirali. Na ta način smo lahko pridobili čim več podatkov o osnovni temi raziskave, poslovni odličnosti $\mathrm{v}$ organizaciji, modelu EFQM ter agilnem menedžmentu.

Uporabili smo kvalitativni način pridobivanja podatkov. S pregledom pridobljene raziskave smo skušali ugotoviti, kateri pristopi krepijo agilnost menedžmenta v poslovno odličnih organizacijah, kako poteka uvedba agilnega menedžmenta $\mathrm{v}$ organizacijo ter kako organizacije razumejo agilni menedžment.

$\mathrm{Z}$ iskanjem po ključnih besedah smo poiskali literature ter članke. Članke smo iskali na Google Učenjak. Za iskanje smo uporabili ključne besede v tabeli 1.

Pri iskanju člankov, smo našli več člankov, ki pa smo jih izključili, saj so se le ti nanašali na agilnost programske opreme, saj se je agilnost začela pojavljati prav tam, kasneje pa so začeli vpeljevati v vseh procesih v organizacijah. Prav tako smo našli več člankov o novem modelu EFQM, za katerega smo se odločili, da ga ne bomo nadomestili z modelom obstoječim modelom, saj je poudarek članka na agilnosti, ki pa izhaja iz modela EFQM (2012). 
Junij / June 2021, leto / year 10, številka / number 2, str. / pp. 155-179.

Tabela 1. Ključne besede za iskanje literature

Ključne besede za iskanje literature
"kakovost"
"poslovna odličnost"
"agilni menedžment"
"pristopi agilnega menedžmenta"
"projektni menedžment"
"agilnost "+agilno vodenje "+organizacijska kultura"
"poslovna agilnost"
"stopnje agilnosti"
"agilnost"
"model EFQM"
"pasti agilnosti"
"agile management"
"agile"
"EFQM model"
"A crital evaluation of the EFQM model"
"theory of agile"
"agile management"

Na spodnji sliki (Slika 2) prikazujemo model raziskave raziskovalnega vprašanja.

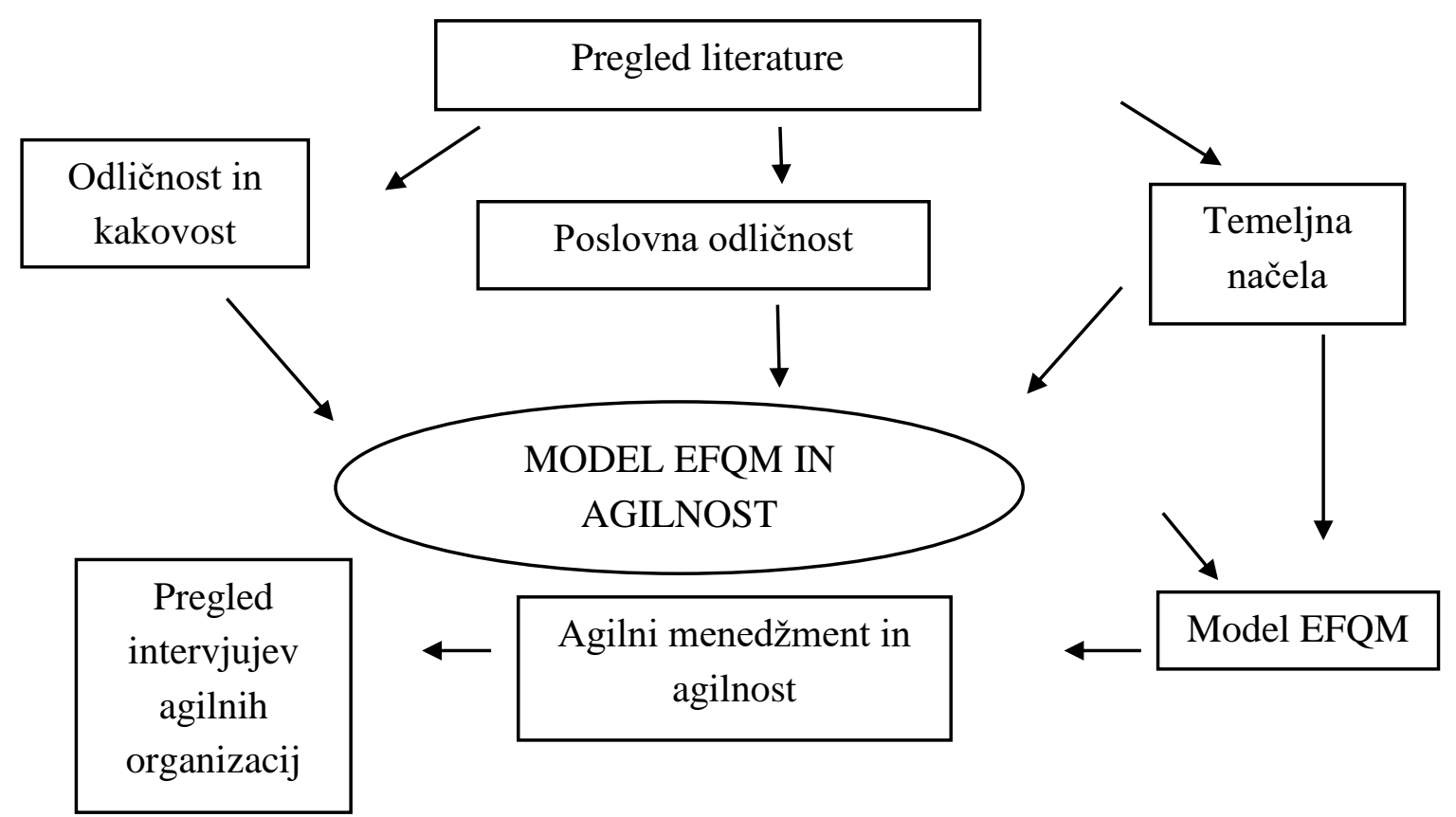

Slika 2. Model raziskave 
Teoretični del smo napisali na podlagi domače in tuje literature. Empirični del pa smo interpretirali na podlagi raziskanih raziskav. Uporabili smo kvalitativni način pridobivanja podatkov. Na podlagi pridobljene literature ter željenih pridobljenih informacij s strani raziskav smo podali kritične zaključke oziroma ugotovitve ter te vsebinsko komentirali.

Članke smo iskali na straneh Google Učenjak, Emerald, SSCI SpingerLink, ProQuest. V pomoč pri iskanju smo si pomagali z več kot 20 ključnimi besedami, s pomočjo katerih smo našli 16 člankov v angleškem jeziku, ter dva članka v slovenskem jeziku. Nekateri članki niso vsebovali raziskav ali pa so le ti vsebovali drugačne raziskave, ki niso ključne za našo izbrano temo (npr. so raziskovali agilnost v programski opremi, ali določenem segmentu, projektnem vodenju, ali je bila raziskava o RADAR metodah,...). Tako smo izbrali 3 raziskave, ki so bile sorodne naši raziskovalni temi tem nam prinesle največ podatkov, katere smo lahko kritično ocenili. Pri iskanju člankov smo jih več izključili, saj so se le ti nanašali na agilnost programske opreme, saj se je agilnost začela pojavljati prav tam, kasneje pa so začeli vpeljevati v vseh procesih v organizacijah. Prav tako smo našli več člankov o novem modelu EFQM, za katerega smo se odločili, da ga ne bomo nadomestili z modelom obstoječim modelom, saj je poudarek članka na agilnosti, ki pa izhaja iz modela EFQM (2012).

Podatki, ki smo jih podali v empiričnem delu so podani na podlagi pridobljene literature ter raziskav. Enota, ki je bila izbrana iz Slovenije temelji na raziskavo, ki so jo vodili CorboHub na področju stanje agilnosti v Sloveniji (CorboHub, 2019). Vsako leto naredijo novo raziskavo na temo agilnosti v Sloveniji in primerjajo rezultate med sabo.

Članek bi bil še bolj zanesljiv, če bi sami naredili intervjuje ter bi intervjuvali agilne organizacije, tako pa smo podali zaključke na podlagi pridobljenih intervjujev oziroma raziskav, ki so jih naredili drugi.

\section{Rezultati}

Po pregledu in izločanju člankov, ki ne zadostujejo navedenim kriterijem, smo za integrativni pregled literature izbrali 2 članka, ter 1 članek iz indeksirane revije. Iz teh člankov smo izpeljali ugotovitve, ki smo jih kategorizirali v tabeli 2 in 3.

Rezultate posameznih raziskav smo med sabo primerjali ter kritično ovrednotili posamezne rezultate. 
Tabela 2. Kategorizacija literature o agilnosti

\begin{tabular}{|c|c|c|c|c|c|c|}
\hline $\begin{array}{c}\text { Raziskovalni } \\
\text { okvir }\end{array}$ & Literatura & $\begin{array}{c}\text { Faktor } \\
\text { vpliva }\end{array}$ & $\begin{array}{c}\text { Pomen } \\
\text { agilnosti }\end{array}$ & $\begin{array}{c}\text { Agilne } \\
\text { organizacije }\end{array}$ & $\begin{array}{l}\text { Prednosti in } \\
\text { slabosti }\end{array}$ & $\begin{array}{l}\text { Agilnost v } \\
\text { Sloveniji }\end{array}$ \\
\hline AGILNOST & $\begin{array}{c}\text { State of } \\
\text { Agile } \\
\text { Slovenia } \\
\text { (CorboHub, } \\
\text { 2019). }\end{array}$ & I & $\begin{array}{l}\text { Vsi člani } \\
\text { morajo imeti } \\
\text { zelo dobro } \\
\text { tehnično } \\
\text { znanje, biti } \\
\text { morajo zelo } \\
\text { motivirani ter } \\
\text { se nenehno } \\
\text { izboljševati. } \\
\text { Prožnost in } \\
\text { sposobnost } \\
\text { prilagajanja } \\
\text { spremembam. }\end{array}$ & $\begin{array}{l}\text { Kakovost članov } \\
\text { agilnih ekip je zelo } \\
\text { pomembna, saj se } \\
\text { pričakuje, da je } \\
\text { agilna ekipa } \\
\text { samoorganizirana } \\
\text { in sposobna sama } \\
\text { razviti produkt } \\
\text { brez zunanje } \\
\text { pomoči. }\end{array}$ & $\begin{array}{l}\text { Pri uvedbi } \\
\text { agilnosti v } \\
\text { organizacijo } \\
\text { je glavno } \\
\text { vprašanje še } \\
\text { vedno } \\
\text { splošni } \\
\text { odpor do } \\
\text { sprememb. } \\
\text { Glavni razlog } \\
\text { za uvedbo } \\
\text { agilnosti pa } \\
\text { so } \\
\text { izboljšanje } \\
\text { učinkovitosti } \\
\text { ekipe. } \\
\text { Organizacije } \\
\text { kot prednost } \\
\text { agilne } \\
\text { organizacije } \\
\text { opazijo } \\
\text { izboljšano } \\
\text { preglednost } \\
\text { pri } \\
\text { poslovanju. }\end{array}$ & $\begin{array}{l}\text { Večina } \\
\text { podjetij že } \\
\text { uporablja } \\
\text { agilnost, } \\
\text { pojmi ki se } \\
\text { navezujejo na } \\
\text { agilnost so } \\
\text { organizacijam } \\
\text { znani. } \\
\text { Organizacije } \\
\text { so se na } \\
\text { agilnost } \\
\text { prilagodile le } \\
\text { deloma, le } \\
\text { določeni } \\
\text { oddelki v } \\
\text { organizacijah. } \\
\text { Organizacij, ki } \\
\text { v celoti } \\
\text { uporabljajo } \\
\text { agilne } \\
\text { metodologije, } \\
\text { pa je še vedno } \\
\text { malo. } \\
\text { Prav tako } \\
\text { organizacijam } \\
\text { in } \\
\text { posameznikom } \\
\text { še vedno ni } \\
\text { jasna } \\
\text { definicija } \\
\text { 'agile' - vsak } \\
\text { posameznik jo } \\
\text { opisuje v } \\
\text { svojem } \\
\text { lastnem } \\
\text { razumevanju. }\end{array}$ \\
\hline
\end{tabular}

Prednosti agilne organizacije se pokažejo v sposobnosti hitrega odziva na spremembe na trgu ali v tehnologiji, sposobnosti prilagajanja s ciljem večje učinkovitosti delovnih procesov, učinkovitem vodstvu, načinu dela s stalno prilagodljivostjo in izboljšavami, hitrostjo, prilagodljivostjo, odzivnostjo, pristopom k optimizaciji dela in razvoju izdelkov, sposobnostjo hitrega in kakovostnega dela, prilagodljivostjo, osredotočenostjo, usmerjenost $\mathrm{k}$ cilju, timskemu delu, hitremu zagotavljanju vrednosti, iterativnim postopkom razvoja izdelkov, prilagodljivostjo za zahteve strank in sposobnostjo hitrega odzivanja. 
Tabela 3. Kategorizacija literature o modelu EFQM

\begin{tabular}{|c|c|c|c|c|c|c|}
\hline $\begin{array}{c}\text { Raziskovalni } \\
\text { okvir }\end{array}$ & Literatura & $\begin{array}{l}\text { Faktor } \\
\text { vpliva }\end{array}$ & $\begin{array}{c}\text { Pomen } \\
\text { EFQM za } \\
\text { organizacijo }\end{array}$ & $\begin{array}{c}\text { Organizacije, ki } \\
\text { imajo vpeljan } \\
\text { model EFQM }\end{array}$ & $\begin{array}{l}\text { Prednosti in } \\
\text { slabosti }\end{array}$ & $\begin{array}{l}\text { Model EFQM v } \\
\text { Sloveniji }\end{array}$ \\
\hline $\begin{array}{l}\text { MODEL } \\
\text { EFQM }\end{array}$ & $\begin{array}{c}\text { Measuring } \\
\text { teamwork } \\
\text { culture: the } \\
\text { use of a } \\
\text { modified } \\
\text { EFQM } \\
\text { model } \\
\text { (Castka, } \\
\text { 2003) }\end{array}$ & 1,69 & $\begin{array}{l}\text { Podjetja, ki } \\
\text { uporabljajo } \\
\text { EFQM, se } \\
\text { zavzemajo } \\
\text { za razvoj } \\
\text { kulture } \\
\text { timskega } \\
\text { dela. } \\
\text { Okvir } \\
\text { modela je } \\
\text { splošno } \\
\text { priznano } \\
\text { orodje, ki } \\
\text { vodi k } \\
\text { poslovni } \\
\text { odličnosti. }\end{array}$ & $\begin{array}{l}\text { Ključ do uspeha } \\
\text { organizacije je } \\
\text { njena } \\
\text { sposobnost, da } \\
\text { se prilagodi } \\
\text { njenem } \\
\text { spreminjajočem } \\
\text { se okolju. } \\
\text { Model EFQM je } \\
\text { primeren za } \\
\text { samoocenitev } \\
\text { uspešnosti } \\
\text { organizacije, in } \\
\text { ta lahko svojo } \\
\text { uspešnost in } \\
\text { zgodbe o } \\
\text { napredovanju in } \\
\text { razvoju delijo z } \\
\text { drugimi. }\end{array}$ & $\begin{array}{l}\text { Spremenjeni } \\
\text { model bi izpolnil } \\
\text { cilj - uskladitev } \\
\text { ukrepov, } \\
\text { učinkovitosti in } \\
\text { zagotavljajo } \\
\text { preprosto, a } \\
\text { močno orodje za } \\
\text { samoocenjevanje } \\
\text { in ocenjevanje } \\
\text { kulture timskega } \\
\text { dela. }\end{array}$ & $\begin{array}{l}\text { Model se } \\
\text { uporablja v } \\
\text { vedno več } \\
\text { organizacijah iz } \\
\text { Slovenije. }\end{array}$ \\
\hline & $\begin{array}{c}\text { European } \\
\text { Foundation } \\
\text { for Quality } \\
\text { Management } \\
\text { Business } \\
\text { Excellence } \\
\text { (Kim, } \\
\text { Kumar, \& } \\
\text { Murphy, } \\
\text { 2010) }\end{array}$ & 2,16 & $\begin{array}{l}\text { Poudarek } \\
\text { modela je na } \\
\text { merjenju } \\
\text { uspešnosti. }\end{array}$ & $\begin{array}{l}\text { Model ima v } \\
\text { organizacijah } \\
\text { celostno } \\
\text { predpostavko: } \\
\text { odlična } \\
\text { uspešnost je } \\
\text { pridobljena s } \\
\text { petimi } \\
\text { možnostmi } \\
\text { (vodenje, } \\
\text { ljudje, politika } \\
\text { in strategije, } \\
\text { partnerstva in } \\
\text { viri ter procesi). }\end{array}$ & $\begin{array}{l}\text { Model EFQM je } \\
\text { eden najboljših } \\
\text { modelov pri } \\
\text { merjenju in } \\
\text { izboljšanju } \\
\text { organizacijske } \\
\text { uspešnosti. }\end{array}$ & $\begin{array}{l}\text { Model EFQM je } \\
\text { razvit za } \\
\text { ocenjevanje } \\
\text { organizacij na } \\
\text { ravni evropske } \\
\text { kakovosti. }\end{array}$ \\
\hline
\end{tabular}

Okvir modela je splošno priznano orodje, ki vodi k poslovni odličnosti in je razvit za ocenjevanje organizacij na ravni evropske kakovosti. Model EFQM je eden najboljših modelov pri merjenju in izboljšanju organizacijske uspešnosti tako $\mathrm{v}$ zasebnem kot javnem sektorju. Model se uporablja v vedno več organizacijah iz Slovenije kot tudi po Evropi. Podjetja, ki uporabljajo EFQM, se zavzemajo za razvoj kulture timskega dela. Spremenjeni model bi izpolnil cilj - uskladitev ukrepov, učinkovitosti in zagotavljajo preprosto, a močno orodje za samoocenjevanje in ocenjevanje kulture timskega dela. Model celostno pokriva vse funkcije organizacije (npr. vodenje, ljudje, politika in strategije, partnerstva in viri ter 
procesi). Model EFQM je primeren za samoocenitev uspešnosti organizacije, in ta lahko svojo uspešnost in zgodbe o napredovanju in razvoju delijo tudi z drugimi organizacijami.

\section{Razprava}

Poslovno okolje zaznamujejo nepredvidljivost, negotovost, kompleksnost in nejasnost. Menedžerji poskušajo $\mathrm{z}$ različnimi metodami in orodji načrtovati in udejanjiti načine delovanja, ki bi zagotovili dolgoročno uspešnost njihovih podjetij v drugih organizacijah. Agilna organizacija predstavlja koncept, ki prinaša del odgovora podjetjem in drugim organizacijam na izzive sodobnega poslovnega okolja.

V teoretičnem deli smo spoznali, da so obstoječe raziskave opredelile ključni pomen agilne organizacije, sicer pa jim je skupno, da imajo take organizacije sposobnost prilagajanja s pomočjo uvedenega učinkovitega upravljanja ter lahko hitro prilagajajo svojo organizacijo v ustrezni organizacijski kulturi. Temelj je sprejel strategijo agilnosti, ki zaobjema celotno raven organizacije, kot tudi vsakega posameznika, ki je vpet v delovanje organizacije. Od agilnih organizacij se pričakuje, da izdelki ali storitve nudijo nove digitalne tehnologije, ki bodo zadovoljile zahteve poslovnih partnerjev po preglednosti dogajanja znotraj njihove življenjskega cikla. (Gajšek \& Kovač, 2019, str. 11)

Da bi organizacije držale korak s konkurenco, se morajo tako stalno izpopolnjevati. Biti morajo odprta za nove priložnosti, agilno pa se morajo odzivati tudi na spremembe. Da so organizacije uspešne, se le te čedalje več poslužujejo modela EFQM, saj le ta predstavlja obširne prednosti za uspešnost organizacij. Okvir modela vodi k poslovni odličnosti in je razvit za ocenjevanje organizacij na ravni evropske kakovosti. Model EFQM je eden najboljših modelov pri merjenju in izboljšanju organizacijske in izpolnjuje cilje organizacije uskladitev ukrepov, učinkovitosti in zagotavljajo preprosto, a močno orodje za samoocenjevanje in ocenjevanje kulture timskega dela. Model je primeren za samoocenitev uspešnosti organizacije, in ta lahko svojo uspešnost in zgodbe o napredovanju in razvoju delijo tudi z drugimi organizacijami.

Model pokriva tudi agilnost organizacije, katere prednosti se pokažejo v sposobnosti hitrega odziva na spremembe na trgu ali $\mathrm{v}$ tehnologiji, sposobnosti prilagajanja s ciljem večje učinkovitosti delovnih procesov, učinkovitem vodstvu, načinu dela s stalno prilagodljivostjo in izboljšavami, hitrostjo, prilagodljivostjo, odzivnostjo, pristopom $\mathrm{k}$ optimizaciji dela in razvoju izdelkov, sposobnostjo hitrega in kakovostnega dela, prilagodljivostjo, osredotočenostjo, usmerjenost $\mathrm{k}$ cilju, timskemu delu, hitremu zagotavljanju vrednosti, iterativnim postopkom razvoja izdelkov, prilagodljivostjo za zahteve strank in sposobnostjo hitrega odzivanja. Vse več organizacij čutijo prisotnost agilne kulture, pa vendar še vedno veliko organizacij ne živi in diha agilne kulture. 


\section{Zaključek}

Ideja o agilnem razvoju informacijskih rešitev in storitev je vse prej kot nova. V kombinaciji s spremenjenimi poslovnimi razmerami, ko vitkost in visoka odzivnost razvojnih ekip več ne predstavlja le konkurenčne prednosti, temveč nujo za obstanek na trgu, so agilne metode razvoja postale ustaljena praksa. Vendar agilnost $\mathrm{v}$ praksi pomeni prav tako strogo urejen nabor pravil in metod, ki z uporabo inženirskih pristopov vodi do delujočih, kakovostnih, dobro dokumentiranih informacijskih rešitev in storitev. Agilni pristopi niso čarobna paličica, ki je sposobna sama po sebi nasloviti številne izzive znotraj razvojnega cikla, temveč so zgolj pomemben pripomoček pri minimiziranju tveganj, povezanih z obsegom, ceno in kakovostjo končnih informacijskih rešitev in storitev. (Pavlič, \& Brezočnik, 2017, str. 79)

Poslovna odličnost je povezana $\mathrm{z}$ doseganjem velikega napredka ali izjemnih rezultatov $\mathrm{z}$ vidika uspešnosti, učinkovitosti, konkurenčnosti in ugleda posamezne organizacije $v$ daljšem obdobju, z upoštevanjem načel odličnosti (Janjetovič, 2019, str 2). Novi časi poslovanja zahtevajo nove pristope in načine vodenja. Ker potrebujemo hitrejše rešitve, potrebujemo drugačen način vodenja. Podjetja bijejo bitko za preživetje in morajo biti nenehno korak pred konkurenco. Agilni menedžment je eden izmen osmih načel modela EFQM in pomeni, da so agilne organizacije priznane zaradi svoje sposobnosti prepoznavanja ter uspešnega in učinkovitega odzivanja na priložnosti in nevarnosti. Pristop modela odličnosti EFQM vsebuje številna merila ki so razdeljeni na pod-kriterije in so namenjeni obravnavanju vseh vidikov za podjetja. (Rusjan, 2005, str. 365)

Agilnost je povezana s sposobnostjo organizacije, da postane konkurenčna, krepi prednost z inteligentnim, hitrim in proaktivnim izkoriščanjem priložnosti in odzivanjem na grožnje. V svojem središču vključuje sposobnost strateškega usmerjanja inovativnih zmogljivosti. (Bessant, Knowles, Briffa \& Francis, 2002, str. 487)

Raziskava (CorboHub, 2019, str. 2-8), ki smo jo preverili, je pokazala, da anketirani čutijo prisotnost agilne kulture v organizacijah, kjer delajo, vendar, da večina organizacij v Sloveniji še zdaleč ne živi in diha agilne kulture. Bistvo agilnosti ni v tem, da delo v takem okolju ni nikoli monotono in dolgočasno, da se poslovni modeli lahko hitro spreminjajo (kar za nobeno podjetje ne drži) ter da podjetje nikoli ne zapade v rutino. Bistvo je v ljudeh - da se znajo hitro obrniti v začetnem bolj turbulentnem obdobju, da imajo dovolj znanj in da jim lahko pri dodeljevanju nalog zaupamo.

Članek smo napisali z namenom, da prikažemo, da agilnost menedžmenta in ustrezna organizacijska kultura pripomoreta $\mathrm{k}$ hitrejšemu prilagajanju okolja, prepoznavanju priložnosti v okolju in konkurenčnosti podjetja. Organizacije, ki sledijo modelu EFQM in svojo organizacijo preorganizira v agilno organizacijo, lahko prinesejo svoji organizaciji velik

doprinos, tudi obstanek na trgu, saj tako držijo korak s konkurenti ali pa so od njih celo boljši, kar je ključno. Organizacije se hitro odzivajo na spremembe in sledijo potrebe svojih kupcev. 
Agilne organizacije so bolj prilagodljive, uspešnejše ter bolj konkurenčne, to pa se kaže tudi v razlikah s tistimi organizacijami, ki ne dihajo agilne kulture. Vodje agilnih organizacij morajo razvijati učinkovite komunikacijske in interakcijske spretnosti. Posamezniki morajo v organizaciji sprejeti skupno vizijo, sodelovati v kulturi zaupanja in vključevanja, medtem ko morajo voditelji spodbujati ustvarjalnost in eksperimentiranje.

Za agilno organizacijo velja, da je ta inovativna, agilna, prilagodljiva, in da je potrebno sprotno prenavljanje poslovanja. Organizacije morajo ustvarjati agilno vodenje organizacije ter vpeljati agilno organizacijsko kulturo saj bodo tako dosegale hitrejše in učinkovitejše prilagajanje spremembam $\mathrm{v}$ okolju. Organizacijo pa tvorimo posamezniki. Zato bi pomanjkanje agilnega vodenja in ustvarjanja neustrezne organizacijske kulture imelo negativen vpliv na zadovoljstvo vseh, ki so vključeni v proces (zaposleni, stranke, dobavitelji,...) in posledično na prilagajanje potrebam okolja, zato se morajo vsi zaposleni oz. agilno ozaveščati, ter sprejeti tako vizijo kot poslanstvo organizacije, v kateri delujejo.

V članku smo razbili mite o pojmu agilnosti in agilni organizaciji, ter prikazali povezavo med modelom EFQM in agilnimi organizacijami. Omejitev naše raziskave pa vendar predstavlja manjše število člankov in literature izbranih za primerjavo. Na podlagi večjega vzorca člankov, bi dobili bolj relevantne rezultate. Prav tako smo našli malo člankov v slovenskem jeziku. 


\section{Reference}

1. Bessant, J., Knowles, D., Briffa, G., \& Francis, D. (2002). Developing the agile enterprise. International Journal of Technology Management, 24(5-6), 484-497.

2. Bric, R. (2013). Poslovna odličnost kot celovito obvladovanje kakovosti upravljanja, kakovosti storitev in učinkovitosti v komunalni dejavnosti. Slovenska fundacija za poslovno odličnost. Pridobljeno na https://konferenca-komunala.gzs.si/pripone /BRIC\%20Rudi_SPFO.pdf

3. Castka, P., Bamber, C. J., \& Sharp, J. M. (2003). Measuring teamwork culture: the use of a modified EFQM model. Journal of management development, 22(2), 149-170.

4. CorboHub (2019). State of Agile Slovenia. Pridobljeno na https://www.corpohub.com/portfolio/state-of-agile-slovenia-2019/

5. Criado-García, F., Calvo-Mora, A., \& Martelo-Landroguez, S. (2019). Knowledge management issues in the EFQM excellence model framework. International Journal of Quality \& Reliability Management, 37(5), 781-800. https://doi.org/10.1108/IJQRM-11-20180317.

6. Denning, S. (2017). Strategic agility: Using agile teams to explore opportunities for marketcreating innovation. Strategy \& Leadership, 45(2), 12-18.

7. Dolinšek, S., Piskar, F., Faganel, A., Kern Pipan, K., Podobnik, D. (2006). Management kakovosti: Zapiski predavanj. Fakulteta za management, Koper.

8. Gajšek, B. \& Kovač, J. (2019). Characteristics of an Agile Organization. Neobjavljen interni dokument.

9. Gómez, J. G., Costa, M. M., \& Lorente, Á. R. M. (2011). A critical evaluation of the EFQM model. International Journal of Quality \& Reliability Management, 28(5), 484-502.

10. Janeš, A. (2019). Agilnost v organizacijah. IBS: Newsletter poročevalec. 9(2). Pridobljeno na //http_porocevalec.ibs.si/?url=http\%3A\%2F\%2Fporocevalec.ibs.si\%2Fs1\%2Fcomponent\%2Fc ontent $\% 2$ Farticle\%2F83-letnik-9-t-2\%2F385-izr-prof-dr-jane-aleksander-agilnost-vorganizacijah

11. Janjetovič, Z. (2019). Človeški viri in poslovna odličnost. Zbornik 6. študentske konference Fakultete za management, Koper. Pridobljeno na http://www.fm-kp.si/zalozba/ISBN/978-961266-033-8/prispevki/Janjetovic\%20Zoran.pdf

12. Kern, P., K., Leon L. (2010). Nova verzija evropskega modela odličnosti EFQM (2010) glavne spremembe in prednosti. Pridobljeno na https://www.podjetniskiportal.si/uploads/gradiva/poslovna_odlicnost/gradiva_pod_poslovno_odlinost/30_dsuportoroz-23-25-sept_2010.pdf

13. Kim, D. Y., Kumar, V., \& Murphy, S. A. (2010). European foundation for quality management business excellence model. International Journal of Quality \& Reliability Management, 27(6), 684-701.

14. Kovačič, A. (2019). Strokovni prispevki. Ali so slovenska podjetja pripravljena na digitalizacijo poslovanja. Pridobljeno na https://uporabnainformatika.si/index.php/ui/article/view/57/50

15. Kutnik, V. Scrum in agilne metode managementa. Blaž Kos Consulting. Pridobljeno na https://www.blazkos.com/scrum-in-agilne-metode-managementa/

16. Ministrstvo za gospodarski razvoj in tehnologijo (2012, 14. februar). Pregled modela odličnosti EFQM. Pridobljeno na https://www.podjetniski- 
portal.si/uploads/gradiva/poslovna_odlicnost/efqm_model_odlicnosti/l_pregled_modela_efqm _2013-zv.pdf

17. Nemšak, M. (2018). Kaj je poslovna odličnost? Štajerska Gospodarska zbornica. Pridobljeno na https://www.stajerskagz.si/kaj-je-poslovna-odlicnost/

18. Nenadál, J. (2020). The New EFQM Model: What is Really New and Could Be Considered as a Suitable Tool with Respect to Quality 4.0 Concept?. Quality Innovation Prosperity, 24(1), 17-28.

19. Nold, H. (2012). Linking knowledge processes with firm performance: organizational culture. Journal of Intellectual Capital, 13 (1), 16-38.

20. Nold, H, in Michel, L. 2016. The performance triangle: a model for corporate agility. Leadership \& Organization Development Journal, 37 (3), 341-356.

21. Pavlič, L., \& Brezočnik, L. (2017). Pasti in zanke agilnih pristopov. Univerzitetna založba, Univerza $v$ Mariboru. Ots sodobne informacijske tehnologije in storitve (zbornik dvaindvajsete konference).

22. Rusjan, B. (2005). Usefulness of the EFQM excellence model: Theoretical explanation of some conceptual and methodological issues. Total Quality Management \& Business

Excellence, 16(3), 363-380.

$* * *$

Patricija Kastelec je leta 2017 diplomirala na Fakulteti za upravljanje in poslovanje Novo mesto, smer menedžment. Najprej je bila nekaj let zaposlena kot optik, nato kot zdravstvena administratorka v privatnem Kirurškem centru. Pri svojem delu je pridobila organizacijske, komunikacijske in vodstvene kompetence. Pri tem gre za pridobitev znanj in izkušenj na različnih področjih, ki so potrebne za nemoteno delovanje organizacije.

\section{Abstract: \\ EFQM Model and Agility of Organizations}

Research question (RV): What is the contribution of an organization that follows the EFQM model and reorganizes its organization into an agile organization?

Purpose: The purpose of the research is to examine the interrelationship between the EFQM model, agility and agile organization, and consequently faster adaptability, greater performance and competitiveness of the agile organization.

Method: The article was based on a review of foreign and domestic literature. We reviewed the professional literature on agility and the EFQM model. We searched a link between agility and the EFQM model.

Results: We will find that there are differences between agile management and organizational culture in organizations that are agile aware from those that are not. It is essential for successful agile organization leaders to develop effective communication and interaction skills that are unique to the leader and organization. It is important that individuals in the organization adopt a shared vision, participate in a culture of trust and inclusion, while leaders encourage creativity and experimentation.

Organization: An agile organization is considered to be fast (innovative, agile, adaptable) and that it is necessary to constantly renew its business. The research will draw attention to the importance and necessity of management awareness that by creating a certain organizational culture and agile management of the organization, they will achieve faster and more efficient adaptation to changes in the environment.

Society: The lack of agile management and the creation of an inappropriate organizational culture has a negative impact on the satisfaction of all involved in the process (employees, customers, suppliers) and consequently on adapting to the needs of the environment. 
Revija za univerzalno odličnost / Journal of Universal Excellence,

Junij / June 2021, leto / year 10, številka / number 2, str. / pp. 155-179.

Originality: The originality of the article lies in breaking down the myths about the concept of agility and agile organization, and presenting or evaluating the obtained results with the result of differences between agile and not agile or traditional organizations.

Limitations / further research: The limitation represents a small number of articles and literature selected for comparison. Based on a larger sample of articles, we would get more relevant results. We also found a few articles in Slovenian.

Keywords: business excellence, EFQM model, agile management, agility, agile organization.

Copyright (c) Patricija KASTELEC

(c) (i) (2)

Creative Commons License

This work is licensed under a Creative Commons Attribution-ShareAlike 4.0 International License. 